УДК 378.147

DOI: $10.24144 / 2524-0609.2021 .48 .320-324$

\author{
Perminova Vladyslava \\ Candidate of Pedagogical Sciences, Ph.D, Associate Professor \\ Foreign Languages for Specific Purposes Department \\ «Chernihiv Polytechnic» National University, Chernihiv, Ukraine \\ vladaperminova@gmail.com \\ ORCID ID: http://orcid.org/0000-0002-5082-6308
}

Sikaliuk Angela

Candidate of Pedagogical Sciences, Ph.D, Associate professor

Foreign Languages for Specific Purposes Department

«Chernihiv Polytechnic» National University, Chernihiv, Ukraine angelasikaliuk@gmail.com

ORCID ID: http://orcid.org/0000-0002-6681-271X

\author{
Shenderuk Olena \\ Candidate of Pedagogical Sciences, Associate Professor \\ Foreign Languages Department \\ Academy of the State Penitentiary Service, Chernihiv, Ukraine \\ shenderuk1@ukr.net \\ ORCID ID: http://orcid.org/0000-0003-4147-327X
}

\title{
THE USE OF ACTIVE TEACHING METHODS IN FORMING THE PROFESSIONAL LANGUAGE COMPETENCE OF STUDENTS
}

\begin{abstract}
The constant need to improve the educational process during the vocational training of students by means of a foreign language, challenges scientists and teachers to explore the most effective approaches to teaching. The aim of the paper is to analyses active teaching methods in the process of forming the professional language competence of students. To study the problem, theoretical methods of pedagogical research have been used by the authors of the article. It has been researched that active teaching methods contribute to the development of thinking skills of student. On the basis of the above examples of active teaching methods, it has been proposed to use the following active methods as Case study, «brainstorming», role play, debates, analysis of specific situations, that encourage students to active mental activity in the process of mastering the educational material. Active teaching methods increase interest and motivation in learning English for specific purposes, develop their independence, contribute to the development of thinking abilities, the ability to express their thoughts in the target language. In parallel with teaching and upbringing, the use of active teaching methods in the educational process ensures the formation and development of so-called universal skills of students. These usually include the ability to make decisions and the ability to solve problems, communication skills and qualities, the ability to formulate messages clearly and set tasks, the ability to listen to and take into account the different points of view and opinions of others, leadership skills and qualities, and the ability to work in a team. The main components of the professionally oriented system are the content of the educational process, the educational activities of the teacher and the activities of students. As a result of interaction of these components there are other elements of system (means, methods and forms, technical means, etc.).
\end{abstract}

Key words: active teaching methods; vocational training; English for specific purposes; professional language competence.

Introduction. Rapid changes in the political and socio-economic development of Ukraine have proved the need to update and modernize the national system of higher education, aimed at improving the quality of educational services, meeting the public needs of highly qualified professionals. Dynamic transformations in today's globalized world determine new requirements for the level of education, training and competence of professionals who will constitute the future national elite, which is the potential for building a developed democratic society.

Ukraine's desire for European integration requires the adaptation of the national higher education system to the needs of the globalized world and the requirements of the European educational space.

Analysis of recent research and publications. Domestic and foreign researchers notethat the use of active teaching methods does not allow to mobilize students effectively to participate in the educational process. The problem of introduction of active teaching methods in teaching but the educational process of higher education is considered in the works of domestic scientists: D.Dolbneva, Y.Ivanenko, G.Lysak, V.Korol, O.Moskalyuk and others.

The perpose of the article is to cover the implementation of active teaching methods during teaching English for specific purposes in non-linguistic higher educational establishments. To study the problem, theoretical methods of pedagogical research have been used by the authors of the article, mainly: analysis, synthesis and modeling, to explain the key drives and key outcomes of the problem being researched; to synthesize prior empirical findings within a theoretical framework of the issue.

Discussion and results. Active teaching methods are methods characterized by a high degree of involvement of students in the educational process, activating their cognitive and creative activity in solving the assigned tasks.

Distinctive features of active teaching methods are: purposeful activation of thinking, when the student is forced to be active regardless of his desire; a sufficiently long time of the trainees' involvement in the educational process, since their activity should not be short-term or episodic, but largely stable and long-term (ie, during 
the entire lesson); independent creative development of decisions, an increased degree of motivation and emotionality of trainees; interactive character (from the English interaction - interaction), ie constant interaction of subjects of educational activity (students and teachers) through direct and feedback, free exchange of views on ways to resolve a particular problem.

The purpose of learning English in is seen as a model of natural learning, whose participants have certain foreign language skills and abilities, as well as the ability to correlate language with the norms of language behavior, which are followed by native speakers. Teaching a foreign language involves the following forms of classes: group work under the guidance of a teacher and individual consultations.

The modeling of the professionally oriented system takes into account the variable and modular approach, the need for which is due to two main reasons: the inability to create a unified model for higher education establishments, the implementation of innovative approaches that depend on psychological, scientific and methodological and organizational training of participants. It also takes into account the means of improving the efficiency of education and training reserves, namely: 1) teacher's speech; 2) educational support: a) methodological support (literature, information resources); b) material and technical support (training and material base and premises).

By reserves we mean: rational organization of training; purposeful organization of teaching material and actions of students; extensive use of internal potential of students' abilities.

Rational organization of education is possible, firstly, due to clear planning of the student's work in the classroom and at home, a well-thought-out distribution of classroom and homework, various exercises and tasks.

Rational organization of training is possible due to the efficient use of time in classrooms in a foreign language. The ratio of activity during the the class should be in favor of students. The teacher is the organizer of students' speech activity.

A more rational organization of learning is achieved on the basis of test methods to control the acquisition of language material and the level of formation of language skills of the student [1].

Purposeful organization of educational material also provides an opportunity to increase the effectiveness of foreign language learning. That is, by the methodological organization is meant: in which case the visual perception should be supported by the auditory, in which it should not be done, which sequence can give a greater pedagogical effect. Successful solution of these and other issues related to the methodological organization of educational material is possible if you take into account the psychological characteristics of students, their perception, memory, thinking activity, their life experience, interests.

The use of the following technologies contributes to the creative application of knowledge, skills and abilities in professionally-oriented disciplines: Case-Study technologies; preparation and presentation of projects; brainstorming; compilation of lexical and grammatical tables; presentation of professional problems and business games; simulation of an imaginary professional situation.

Case study technology (analysis of specific situations) is the creation of a problem situation based on real life events. For the effective formation of foreign language communicative competence on the basis of the casemethod method, two components are needed: an actual problem situation (case) and an effective methodological system of its application in educational activities [2]

A well-thought-out case must correspond the following requirements: meet the goal; meet a certain level of difficulty; reflect the problem from different points of view; have a national and cultural content; be relevant; reflect professional situations typical to the sphere of professional activity; to develop analytical and critical thinking, to generate discussion; have several solutions. The case can be presented in printed version, with the addition of texts, diagrams, tables, and with the help of modern multimedia tools.

There are the following stages for creating cases: goal setting; the concept of purpose and a certain real problem situation; search for the necessary information; collection and systematization of information for the Case; preparation of the initial presentation of the material in the Case; maintenance of the problem situation with the introduction of the necessary changes in the Case.

As a task, students can be offered a specific problem or provided with a text to read and offered to prepare a meeting with the client in order to provide advice; or outline a contentious issue for clarification.

The project method is an effective technology for the formation and integration of general professional competence of future specialists.

Design technology is one of the most effective for the development of creative abilities of students. Working on creating projects on a particular topic, students look for new ideas, trying to implement them brightly, interestingly, irregularly. Therefore, project work helps a teacher to intensify the activities of students, encourage them and encourage independent creative search.

The main task of the teacher in teaching English for specific purposes is to shift the emphasis from various exercises to creative mental activity, which requires mastery of certain language tools. The project method allows solve this didactic problem, and accordingly turn practical English classes into a discussion, research club, which on the basis of intercultural interaction solves really interesting, practically significant and accessible problems for students, taking into account the peculiarities of the culture of the country [3].

At the heart of the project there is a certain issue, for the solution of which students need not only the knowledge of English, but also knowledge of special disciplines, necessary and sufficient for its solution. To solve the professional problem underlying the project, students need not only to speak a foreign language as a means of communication, but also to update the knowledge, skills, abilities acquired in the study of special disciplines, without which quality project implementation is impossible.

Work on the project includes the following stages:

1. Defining the topic, setting tasks, choosing the type of project work, the number of participants;

2. Consultation of the teacher at definition of project problems and independent nomination of problems by students;

3. Distribution of project tasks in the group, discussion of optimal methods of project implementation, methods of searching and working with information;

4. Independent performance of individual and group project tasks: conducting research, creative processing of material;

5 . Interim discussions of individual and group results of project work;

6. Defense (presentation) of the project;

7. Collective analysis, evaluation and self-evaluation of project results, conclusions and generalizations.

Thus, the use of design technology contributes to: 
1. Effective formation of communicative competence of students in all types of speech activity;

2. Improving general professional competence;

3. Integration of knowledge on the subject «Foreign language for specific purposes» and professionallyoriented disciplines;

4. Development of the ability to apply the acquired knowledge in practical professional activities, the ability to find the best, creative ways to solve professional problems;

5. The use of modern technologies for information retrieval and processing;

6. Development of reflection and creative abilities of students;

7. Development of independence, activity, desire for self-education and self-improvement;

8. Formation of professional and moral values of future specialists;

9. Forming a mutual understanding of a sense of responsibility to the participants of joint activities.

The main part of the work on the project is carried out by students independently. The role of the teacher is to create favorable conditions for creative self-realization of students, to coordinate the activities of students, in the ability to overcome unforeseen difficulties.

The technology of forming a productive cognitive atmosphere is based on creative activity, which begins with a problem or question, with surprise, with contradiction. The basis of creativity is a search activity that promotes self-development and self-improvement of the student $[4$, p.3].

Role-playing can be considered as one of the effective methods of forming the professional language competence of future professionals. Role play involves the performance of various professional roles, the development of communication within the professional context and in conditions as close as possible to the conditions of real communication. Role-playing is an accurate model of real communication, because it reflects the performance of various roles of the future specialist; in it as well as in real life speech behavior intertwines.

The educational process of future bachelors in English language classes in the professional field involves a comprehensive approach to modeling its content, forms, methods in accordance with the goal. Aiming to prepare future professionals for creative activities, the teacher models the content of the lesson, develops forms and methods of work, taking into account the peculiarities of the tasks, which are focused on further creative activity.

Problem situations contribute to the creation of conditions for independent acquisition of knowledge. Students solve a cognitive task that contains contradictions, provokes discussion, reflection, research and conclusions.

The technology of using educational games and creative tasks is closely connected with the development of the student's creative personality. In the process of solving creative tasks, students create a certain creative product.

When studying various professionally oriented topics, it is advisable to use different types of creative tasks, as it encourages students to search for the novelty.

The process of improving the effectiveness of foreign language teaching in a professional field, which should encourage creative activity, directly depends on the feasibility of selection and use of various, relevant to the curriculum, topics and teaching methods, as well as the activation of the entire educational process. This is facilitated by interactive technologies in English classes [5].

We see the importance of developing and using in- novative and leading forms of organization of classes in the educational process in improving the quality of specialist training. The advantages of using non-traditional forms of organization of classes are as follows: a) increasing the cognitive activity of students, interest in learning activities; b) development of initiative, creative potential of the student's personality; c) prevention of fatigue, creating a comfortable environment for learning and education; d) creating conditions for the formation of professionally significant skills; e) the formation of operational professional skills.

«Brainstorming» is an exercise in which students work together or individually to develop the semantic field of any word or topic. This concept is based on the techniques of semantic associations (word association).

Students spontaneously express ideas, thoughts in the form of individual words, expressions, short sentences based on keywords, concepts, topics, thus creating a basis for further oral and written statements. The method of brainstorming is especially effective in group creative work, because it allows students, with different levels of foreign language proficiency, to contribute to the development of a common idea or topic. The method of brainstorming develops creative professional abilities, openness of thinking, ability to work collectively, actualizes their language experience.

Interactive learning technologies can be divided into four groups depending on the purpose of the lesson and the forms of organization of educational activities: technologies of cooperative learning; technologies of collective and group learning; technologies of situational modeling; technologies for evaluating discussion issues.

Interactive technologies of cooperative learning provide pair and group work, which is organized both in practical learning classes and during the application of knowledge, skills and abilities.

Collective group learning technologies involve the simultaneous (frontal) work of the whole group.

Technologies of situational modeling and assessment of discussion questions involve the creation of interesting non-traditional situations and the setting of clear professional tasks, performing which students must connect the imagination, fantasy, creative thinking.

Creative abilities certainly develop and improve when learning creative writing. To learn writing a text of a given format and characteristics, it is necessary to create in students the image of the future text through the analysis of the proposed text-sample and consideration of its characteristics: structure, logic, coherence, language design, etc. In this case, the text is the basis of analytical activities.

Innovative forms of classes have a huge educational, developmental, cognitive and educational potential and contribute to the formation of professional language competence of the future specialists, as well as contribute to the acquisition of professional knowledge, skills; means of solving professional problems, contribute to the formation of professional values, creativity of future professionals, increasing motivation and formation of professionally significant qualities.

Thus, based on the analysis of scientific and methodological literature, exploring the process of modeling in pedagogy, taking into account the analysis of competencies required for students, based on the study of professionally oriented disciplines (on the example of a foreign language for specific purposes) activities, the experimental verification of which is a prospect for our further study.

The training of a modern competent specialist is characterized not only by critical thinking, mobility, constructiveness, creative attitude to the case, the desire 
for continuous acquisition of knowledge, but also positive motivation for successful professional activity. This highlights the need in the process of higher education to form in the future specialist such an attitude to the profession, in which the professional activity is seen not only as a means of solving material problems, but also as a basic life value, as a means of social self-realization.

A necessary condition for successful professional activity and further self-development of specialists is not only the acquired amount of knowledge in the specialty, but also the ability of future bachelors to apply them creatively in the implementation of professional tasks, as well as the ability to communicate abroad professionally.

An important area of improving the professional training of future specialists is the objective modernization of the educational process with the active use in the process of training personnel of advanced tools and methods of teaching, strengthening the connection between the educational process and practice.

It is necessary that a future bachelor not only has a certain amount of knowledge, but also be able to apply this knowledge in practice. One of the ways to solve these problems is the introduction of contextual learning, which provides the transition, the transformation of cognitive activity into a professional one with a corresponding change in needs and motives, goals, actions, means, objects and results. Such training gives integrity, systemic organization and personal content to the acquired knowledge.
Considerable attention in the process of training students should be paid to the problem of formation and development of the future specialist, focused on success. This cannot be achieved without the formation of the need for self-education as a conscious independent change of personality.

The readiness of the future bachelors for self-improvement after graduation is the student's ability to independently and creatively carry out the whole range of self-educational actions: goal setting, planning, selforganization, self-stimulation, self-education.

Conclusions. Thus, active methods of teaching are innovative methods that are efficient tools when used in training and educational process not only for students but also for teachers. With these methods you can deepen students' knowledge, expand their interests, develop creative ideas and put forward new concepts, communicate with other people. The use of active teaching methods provides an opportunity for scientific and pedagogical employees understand their students better so as their emotions, feelings, character and perception of teaching material. The prospects for further research are directed towards further enchantment of the educational process at higher educational establishments in order to improve the readiness of students for subsequent professional activity. The scientific prospects of the study aim at updating the content and ways of development of professional competence of students by means of foreign language.

\section{Список використаної літератури}

1. Активізація навчального процесу у сучасній вищій школі: методичний огляд / уклад. Л.А.Якимова. Київ : ДП «Вид. дім «Персонал», 2010.32 c.

2. Мойсеєнко Р.М. Активізація пізнавальної діяльності майбутніх фахівців засобами активних методів навчання в умовах університетської освіти. Наукові записки. Серія: Педагогічні науки. 2017. Випуск 159. С.97-103.

3. Cherney I.D. (2008). The Effects of Active Learning on Students' Memories for Course Content. Journal of Active Learning in Higher Education, 2008. Vol. 9. № 2. PP.152-171.

4. Bonwell Ch., Eison J. Active Learning: Creating Excitement in the Classroom. Information Analyses. 1991 ERIC Clearinghouse Products. Washington, DC: Office of Educational Research and Improvement (ED), 1991. $121 \mathrm{p}$.

5. Marx R.W., Blumenfeld P.C., Krajcik J., Soloway E. Enacting project-based science: challenges for practice and policy. Elementary School Journal. Vol. 94. № 5. PP.341-358.

\section{References}

1. Yakymova, L.A. (Ed.). (2010). Aktyvizatsiya navchalnoho protsesu u suchasnii vyschyi shkoli: metodychnyi ohliad [Activation of the educational process in modern higher education: a methodological review]. Personal. [in Ukrainian].

2. Moiseenko, R.M. (2017). Aktyvizatsiia piznavalnoi diyalnosti maibutnikh fakhivtsiv zasobamy aktyvnykh metodiv navchannia $\mathrm{v}$ umovakh universytetskoi osvity [Activation of cognitive activity of future specialists by means of active teaching methods in the conditions of university education]. Naukovi zapysky. Seriya: Pedahohichni nauky, 159, 97-103. [in Ukrainian].

3. Cherney, I. D. (2008). The Effects of Active Learning on Students' Memories for Course Content. Journal of Active Learning in Higher Education, 9 (2), 152-171.

4. Bonwell, Ch., \& Eison, J. (1991). Active Learning: Creating Excitement in the Classroom. Information Analyses. 1991 ERIC Clearinghouse Products. Office of Educational Research and Improvement.

5. Marx, R.W., Blumenfeld, P.C., Krajcik, J., \& Soloway, E. (1997). Enacting project-based science: challenges for practice and policy. Elementary School Journal, 94 (5), 341-358.

Стаття надійшла до редакції 11.04.2021 р. Стаття прийнята до друку 16.04.2021 р. 
Пермінова Владислава

кандидат педагогічних наук, доцент

кафедра іноземних мов професійного спрямування

Національний університет «Чернігівська Політехніка», м.Чернігів, Україна

Сікалюк Анжела

кандидат педагогічних наук, доцент

кафедра іноземних мов професійного спрямування

Національний університет «Чернігівська Політехніка», м. Чернігів, Україна

\author{
Шендерук Олена \\ кандидат педагогічних наук, доцент \\ кафедра іноземних мов \\ Академія Державної пенітенціарної служби, м.Чернігів, Україна
}

\title{
ВИКОРИСТАННЯ АКТИВНИХ МЕТОДІВ НАВЧАННЯ У ФОРМУВАННІ ПРОФЕСІЙНОӤ МОВНОЇ КОМПЕТЕНЦІЇ СТУДЕНТІВ
}

Анотація. Постійна потреба вдосконалювати навчальний процес під час професійного навчання студентів за допомогою іноземної мови викликає у науковців та викладачів вивчення найбільш ефективних підходів до навчання. Метою статті є аналіз активних методів навчання у процесі формування професійної мовної компетентності студентів. Для вивчення проблеми авторами статті використані теоретичні методи педагогічного дослідження. Досліджено, що активні методи навчання сприяють розвитку у студента навичок мислення. На основі вищезазначених прикладів активних методів навчання було запропоновано використовувати такі активні методи, як кейс-стаді, «мозковий штурм», рольова гра, дебати, аналіз конкретних ситуацій, які спонукають студентів до активної розумової діяльності в процесі засвоєння навчального матеріалу. Активні методи навчання підвищують інтерес та мотивацію до вивчення англійської мови професійного спрямування, розвивають їх самостійність, сприяють розвитку здібностей мишлення, здатності висловлювати свої думки мовою професійного спрямування. Паралельно з викладанням та вихованням використання активних методів навчання у навчальному процесі забезпечує формування та розвиток так званих універсальних навичок студентів. До них, як правило, належать здатність приймати рішення та здатність вирішувати проблеми, навички та якості спілкування, здатність чітко формулювати повідомлення та ставити завдання, вміння слухати та враховувати різні точки зору та думки інших, управлінські навички та якості, а також вміння працювати в команді. Зазначено, що основними компонентами професійно орієнтованої системи є зміст навчального процесу, навчальна діяльність викладача та діяльність студентів. В результаті взаємодії цих компонентів виникають інші елементи системи (засоби, методи та форми, технічні засоби тощо).

Ключові слова: активні методи навчання; професійне навчання; іноземна мова професійного спрямування; професійна мовна компетентність. 